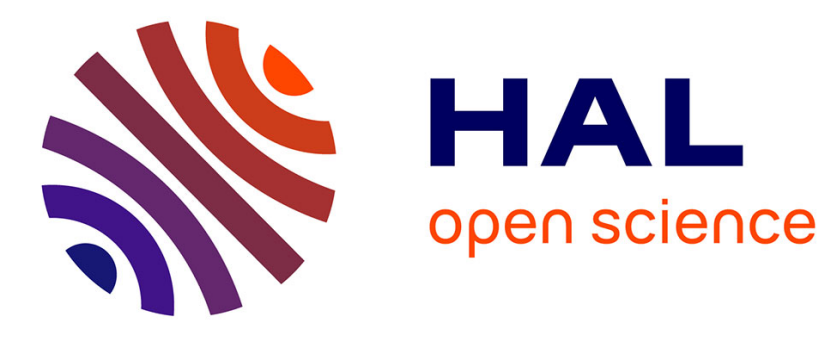

\title{
The minor ecdysteroids from Ajuga turkestanica
}

Louis Guibout, Nilufar Mamadalieva, Christine Balducci, Jean-Pierre Girault,

René Lafont

\section{To cite this version:}

Louis Guibout, Nilufar Mamadalieva, Christine Balducci, Jean-Pierre Girault, René Lafont. The minor ecdysteroids from Ajuga turkestanica. Phytochemical Analysis, 2015, 26 (5), pp.293-300 10.1002/pca.2563 . hal-01157962

\section{HAL Id: hal-01157962 \\ https://hal.sorbonne-universite.fr/hal-01157962}

Submitted on 29 May 2015

HAL is a multi-disciplinary open access archive for the deposit and dissemination of scientific research documents, whether they are published or not. The documents may come from teaching and research institutions in France or abroad, or from public or private research centers.
L'archive ouverte pluridisciplinaire HAL, est destinée au dépôt et à la diffusion de documents scientifiques de niveau recherche, publiés ou non, émanant des établissements d'enseignement et de recherche français ou étrangers, des laboratoires publics ou privés. 
Louis Guibout ${ }^{\mathrm{a}, \mathrm{b}}$, Nilufar Mamadalieva ${ }^{\mathrm{c}}$, Christine Balducci ${ }^{\mathrm{b}}$, Jean-Pierre Girault ${ }^{\mathrm{d}}$ and René Lafont ${ }^{a *}$

a Sorbonne Universités, UPMC Univ Paris 06, IBPS-BIOSIPE, CNRS FR 3631, 7 Quai Saint Bernard, Case Courrier 29, 75252 Paris Cedex 05, France

${ }^{b}$ Institut Biophytis, F-93230 Romainville, France

${ }^{c}$ Institute of the Chemistry of Plant Substances, Mirzo Ulugbek Str. 77, Tashkent 100170, Uzbekistan

${ }^{d}$ Université Paris Descartes, Laboratoire de Chimie et Biochimie Pharmacologiques et Toxicologiques, CNRS UMR 8601, 45 rue des Saints-Pères, F-75270 Paris Cedex 06, France

*rene.lafont@upmc.fr

\section{ABSTRACT}

Introduction - Ajuga turkestanica is a plant used in traditional medicine for its high ecdysteroid content, including the presence of the particularly active turkesterone, which possess efficient anabolic activity.

Objectives - To isolate and identify minor ecdysteroids present in a semi-purified plant fraction containing ca. $70 \%$ turkesterone.

Material and Methods - Multi-step preparative HPLC (combining RP- and NP-HPLC systems) was used to purify the different components present in the turkesterone fraction. Isolated compounds were identified by high-resolution mass spectrometry and 2D-NMR.

Results - Fourteen ecdysteroids (including turkesterone and 20-hydroxyecdysone) were isolated. Seven of these, all bearing an $11 \alpha$-hydroxy group, were previously unreported..

Conclusion - Ajuga turkestanica ecdysteroids are characterized by the abundance of $11 \alpha$-hydroxylated compounds and by the simultaneous presence of $24 \mathrm{C}, 27 \mathrm{C}, 28 \mathrm{C}$ and 29C ecdysteroids. It is expected that even more ecdysteroids are to be found in this plant since the starting material for this study lacked the less polar ecdysteroids. The simultaneous presence of 20-hydroxyecdysone and turkesterone (its 11 $\alpha$-hydroxy analogue) as the two major ecdysteroids suggests that every ecdysteroid is probably present in both $11 \alpha$-hydroxy and 11-deoxy forms.

Keywords: Ajuga turkestanica; Lamiaceae; phytoecdysteroid:

Introduction

Among the $>300$ known species of the genus Ajuga (Lamiaceae), $\geq 45$ have been chemically investigated. A few of these have been studied in the context of their medical properties, owing to the presence of active molecules such as phytoecdysteroids, diterpenoids, sterols, iridoids, neoclerodanes, anthocyanins, other flavonoids and ionones (Israili and Lyoussi, 2009; 
Mamadalieva et al., 2013). Ajuga turkestanica, is naturally growing in Uzbekistan and Tadzhikistan (Vvedenskiy, 1961; Ganiev et al., 1990), and it has been valued for a long time by the local population for its beneficial effects on muscle strength, muscular and stomach aches and its protective action against heart diseases (Cheng et al., 2008; Grace et al., 2008). Many effects have been documented concerning either extracts or pure compounds isolated from $A$. turkestanica aerial parts or roots. Thus, extracts were shown to increase lactation in female rats (Khalitova et al., 1998), to reduce hyperglycaemia in alloxan-induced diabetic rats (Kutepova et al., 2001), to help skin wound healing (Syrov et al., 1994) or to display antiproliferative, antimicrobial and antioxidant effects (Mamadalieva et al., 2013). Most of these effects are probably related to the presence of ecdysteroids (Dinan, 2009). Ecdysteroid-enriched extracts of $A$. turkestanica (or pure turkesterone) display anabolic effects on muscles (Syrov et al., 2001; Zubeldia et al., 2012), even in a sarcopenia context (Lawrence, 2012). In addition, turkesterone and 20-hydroxyecdysone have anti-stress and immunostimulating effects (Shakhmurova et al., 2010). Extracts of Ajuga turkestanica are already marketed for all these indications (e.g. AYUSTAN - http://5741.uz.all.biz/preparat-ayustan-g22268), and turkesterone-enriched extracts are sold on the internet for bodybuilders.

Ajuga turkestanica was one of the early plant species investigated for the presence of ecdysteroids. Firstly, 20-hydroxyecdysone and cyasterone were isolated (Usmanov et al., 1971), then turkesterone (Usmanov et al., 1973, 1975) and several minor components i.e., ajugalactone (Saatov et al., 1977), cyasterone 22-acetate (Usmanov et al., 1978a), ajugasterone B (Usmanov et al., 1978b). More recently, ecdysone and 20-hydroxyecdysone 2,3-acetonide were also indentified (Saatov et al., 1999). Turkesterone and 20hydroxyecdysone (figure 1) are the two major ecdysteroids, accounting each for ca. $0.2-0.4 \%$ of dry weight of aerial parts (Abdukadirov et al., 2005)

It is well-established that ecdysteroid-rich plants such as Silene otites (Báthori et al., 1999), or Rhaponticum carthamoides (Kokoska and Janovska, 2009; Zhang et al., 2010) contain a complex cocktail of various ecdysteroids. Given the high concentrations of ecdysteroids in $A$. turkestanica (ca. 1\% of dry weight), this plant was expected to contain a much larger set of minor ecdysteroids than already described, and the present work has taken advantage of a medium-scale extraction experiment to isolate and identify additional minor ecdysteroids from this plant.

\section{Materials and methods}

Plant material

Roots of $A$. turkestanica were collected in the Surkhan-Darya region of Uzbekistan and identified by Dr. O.A. Nigmatullaev at the Department of Herbal Plants (Institute of the Chemistry of Plant Substances, Uzbekistan) (voucher specimen number 20077092).

\section{Extraction}

Roots of $A$. turkestanica were air-dried in windy place at $23^{\circ} \mathrm{C}$ during one week after collection and them ground to a powder with a Waring blender. After grinding, plant material $(2 \mathrm{~kg})$ was triturated with methanol $(3 \times 6 \mathrm{~L})$ during 3 days at room temperature $\left(23^{\circ} \mathrm{C}\right)$. The solvent was evaporated (in a rotary vacuum evaporator at $40^{\circ} \mathrm{C}$ ) and concentrated, and $102 \mathrm{~g}$ of dried extract was obtained (yield was $5.1 \%$ of the dried plant material). Methanol $(60 \mathrm{~mL})$ was added to the dried methanol extract to fluidize it before diluting with water $(1 \mathrm{~L})$ and hydrophobic compounds were removed upon partition with chloroform $(4 \times 1 \mathrm{~L})$ which was discarded. The water layer $(1 \mathrm{~L})$ was then extracted with $n$-butanol $(5 \times 1 \mathrm{~L})$. The combined butanol extracts were evaporated to dryness under reduced pressure (at $46^{\circ} \mathrm{C}$ ). 
The $n$-butanol fraction (42 g) was chromatographed over a silica gel column (silica particle size: 63 - $100 \mu \mathrm{m}$; Chemapol, Praha, Czech Republic). The column was packed using a simple drypack method. The n-butanol extract applied in dried form mixed with silica gel and carefully added to the top of the column. The column $(1.6 \mathrm{~kg}$ silica, size $10 \times 60 \mathrm{~cm})$ was eluted with $\mathrm{CHCl}_{3} / \mathrm{CH}_{3} \mathrm{OH}(9: 1 \mathrm{v} / \mathrm{v}, 4 \mathrm{~L})$, and fraction $\mathrm{X}$ was obtained containing a mix of less polar ecdysteroids. Continuous elution with $\mathrm{CHCl}_{3} / \mathrm{CH}_{3} \mathrm{OH}(6: 1 \mathrm{v} / \mathrm{v}, 3 \mathrm{~L})$ gave of fraction $\mathrm{Y}$ contained a mixture of 20-hydroxyecdysone, turkesterone and some less polar ecdysteroids. Further elution with $\mathrm{CHCl}_{3} / \mathrm{CH}_{3} \mathrm{OH}(4: 1 \mathrm{v} / \mathrm{v}, 4 \mathrm{~L})$ gave a polar fraction $\mathrm{Z}$, which contained a small amount of turkesterone and iridoids. Eluates were checked by TLC. TLC was performed on aluminium foilbacked plates (Fluka, Sigma-Aldrich, Germany). Developing solvent was chloroform-methanolwater at 4:1:0.1 (v/v/v). Spots were visualized under UV light $(254 \mathrm{~nm})$ and by spraying with vanillin/ $\mathrm{H}_{2} \mathrm{SO}_{4}$ reagent followed by heating to $120{ }^{\circ} \mathrm{C}$ for $10 \mathrm{~min}$ (Báthori and Kalász, 2001). Fractions $\mathrm{X}$ and $\mathrm{Y}$ were combined and after evaporating the solvent under reduced pressure, an ecdysteroid-containing fraction (turkesterone +20 -hydroxyecdysone + less polar ecdysteroids) of $8.3 \mathrm{~g}$ was obtained.

\section{HPLC separations}

An aliquot $(700 \mathrm{mg})$ of the above extract was purified by preparative reversed-phase HPLC (System 1).

Preparative RP-HPLC step (System 1): LC-MS Prep Agilent 1100, Column Sunfire Prep C18 OBD $100 \times 19 \mathrm{~mm}(5 \mu \mathrm{m})$ from Waters; Linear gradient: $\mathrm{A}=\mathrm{ACN}, \mathrm{B}=\mathrm{H}_{2} \mathrm{O}+0.1 \% \mathrm{HCOOH}(\mathrm{T}=0$ $10 \% A-90 \% B ; T=25 \min 35 \% A-65 \% B ; T=26 \min 10 \% A-90 \% B ; T=30 \min 10 \% A-90 \%$ B); Flow-rate $=20 \mathrm{~mL} \cdot \mathrm{min}^{-1}$; detection: UV, wavelength $=254 \mathrm{~nm}$. The extract was dissolved in $35 \mathrm{~mL}$ of $\mathrm{ACN} / \mathrm{H}_{2} \mathrm{O}(10 / 90, \mathrm{v} / \mathrm{v}) .14$ aliquots of this solution were injected into the LC-MS Prep. Fractions were collected using an automatic collector (Agilent Prep-FC G1346B) with a timebased trigger mode. Collected peaks were dried using a HT4-Genevac without heating.

The purity of the above fractions was checked by analytical NP-HPLC (column ACE 5 SII, 150 $x$ 4.6 mm) eluted at $1 \mathrm{~mL} \cdot \mathrm{min}^{-1}$ using either dichloromethane-isopropanol-water (125:40:2.5 $\mathrm{v} / \mathrm{v} / \mathrm{v})$ or cyclohexane-isopropanol-water $(100: 40: 2.5 \mathrm{v} / \mathrm{v} / \mathrm{v})$. Those giving a single peak with both systems were considered as pure enough. Those giving several peaks were further fractionated using the most appropriate NP-HPLC solvent with a semi-preparative Zorbax-SIL column (250 x $9.4 \mathrm{~mm}$ ) eluted at $4 \mathrm{~mL} \cdot \mathrm{min}^{-1}$ using three different solvent systems: dichloromethaneisopropanol-water (125:40:2.5 v/v/v) (system 2a), dichloromethane-isopropanol-water (125:30:2 $\mathrm{v} / \mathrm{v} / \mathrm{v}$ ) (system 2b), and cyclohexane-isopropanol-water (100:40:2.5 v/v/v) (system 3); detection: UV, wavelength $=254 \mathrm{~nm}$. In some cases, two NP-HPLC steps were required to obtain pure compounds.

HPLC-MS analyses

Analytical HPLC-MS used a LC1100 Agilent system with a Sunfire column (50 x $4.6 \mathrm{~mm})$. Elution was performed in the gradient mode: acetonitrile- $0.1 \%$ TFA in $\mathrm{H}_{2} \mathrm{O}$, linear gradient 10 to $35 \%$ acetonitrile in $25 \mathrm{~min}$, flow-rate $=0.5 \mathrm{~mL} \mathrm{~min}^{-1}$. The mass spectrometer was an API 365 equipped with a Turbo Ion Spray source.

\section{HRMS analyses}

High-resolution p-ESI (probe electrospray ionization) mass spectra were acquired with an ultrahigh resolution mass spectrometer, a hybrid linear ion trap LTQ-Orbitrap (Thermo Fisher Scientific, Les Ulis, France). Individual compounds dissolved in methanol were directly infused in the mass spectrometer. For each compound, we observed ions corresponding to [M+Na] ${ }^{+}$ (major), $[\mathrm{M}+\mathrm{K}]^{+}$(medium) and $[\mathrm{M}+\mathrm{H}]^{+}$(minor). 
NMR analyses

All NMR spectroscopy experiments were recorded on a Bruker AVANCE II 500 Spectrometer in $\mathrm{D}_{2} \mathrm{O}\left(500 \mathrm{MHz}\right.$ for ${ }^{1} \mathrm{H}$ and $125 \mathrm{MHz}$ for $\left.{ }^{13} \mathrm{C}\right)$, at $300 \mathrm{~K}$ (Girault, 1998). Presaturation of the solvent was used for all 1D and homonuclear 2D ${ }^{1} \mathrm{H}$ experiments. 2D-experiments $\left({ }^{1} \mathrm{H}\right.$, TOCSY [spin lock time $15 \mathrm{~ms}$ and 35ms], NOESY [mixing time $500 \mathrm{~ms}$ ], HSQC [one bond correlation ${ }^{1} \mathrm{~J}^{1} \mathrm{H}^{-13} \mathrm{C}$ ] and $\mathrm{HMBC}\left[{ }^{1} \mathrm{H}-{ }^{13} \mathrm{C}\right.$ correlation via two or three bonds via ${ }^{2} \mathrm{~J}^{1} \mathrm{H}_{-}{ }^{13} \mathrm{C}$ or ${ }^{3} \mathrm{~J}^{1} \mathrm{H}-{ }^{13} \mathrm{C}$, long-range delay $80 \mathrm{~ms}$ ) were performed by Pulse Field Gradient (PFG) methods using standard Bruker software. The samples were lyophilized and dissolved in $\mathrm{D}_{2} \mathrm{O}$. The sodium salt of 3(trimethylsilyl)[2,2,3,3- $\left.\mathrm{d}_{4}\right]$ propionic acid $\left(T S P-\mathrm{d}_{4}\right)$ was used as internal reference for the proton and carbon shifts. For ${ }^{1} \mathrm{H} 1 \mathrm{D}$ measurements, spectral width of $6009.6 \mathrm{~Hz}$ and $32 \mathrm{~K}$ data points were used to yield the Fid corresponding to a digital resolution of $0.0004 \mathrm{ppm} /$ point $\left(0.18 \mathrm{~Hz} /\right.$ point). So for signals assigned directly from ${ }^{1} \mathrm{H} 1 \mathrm{D}$ measurements accurate values of the chemical shifts could be given $\pm 0.001 \mathrm{ppm}$. However, for ${ }^{1} \mathrm{H} 2 \mathrm{D}$ measurements (TOCSY or NOESY), the same spectral width in $\mathrm{F} 2\left({ }^{1} \mathrm{H}\right)$ of $5000 \mathrm{~Hz}$ was used and all data points (t2 $x \mathrm{t} 1$ ) were acquired with $4 \mathrm{~K} \times 256$. For $\mathrm{F} 1$, linear prediction to 4 times $\mathrm{t} 1$ was applied to enhance the resolution. With these conditions, the digital resolutions are $0.005 \mathrm{ppm} /$ point and $0.01 \mathrm{ppm} / \mathrm{point}$ for F2 and F1, respectively. In the case of heteronuclear experiments (HSQC and HMBC), the same spectral width in F2 $\left({ }^{1} \mathrm{H}\right)$ of $5000 \mathrm{~Hz}$ was used for both. Spectral widths in $\mathrm{F} 1\left({ }^{13} \mathrm{C}\right)$ of $20120 \mathrm{~Hz}$ and $28923 \mathrm{~Hz}$ for HSQC and HMBC, respectively were used. All data points (t2 x t1) were acquired with $4 \mathrm{~K} \times 256$ (or 160), and linear prediction to 4 times t1 was applied to enhance the resolution in $\mathrm{F} 1$. In these conditions, the digital resolutions for $\mathrm{F} 2\left({ }^{1} \mathrm{H}\right)$ are $0.005 \mathrm{ppm} /$ point for HSQC and HMBC, 0.1 ppm/point for $\mathrm{F} 1\left({ }^{13} \mathrm{C}\right) \mathrm{HSQC}$ and $0.2 \mathrm{ppm} /$ point for $\mathrm{F} 1\left({ }^{13} \mathrm{C}\right) \mathrm{HMBC}$.

\section{Results and discussion}

Isolation of ecdysteroids

Preparative HPLC (system 1) allowed the separation and collection of 8 fractions (Figure 2 and Table 1). The purity of each fraction was checked by analytical NP-HPLC-UV. Fractions $1(=$ turkesterone), 4 (=20-hydroxyecdysone), 5, 6 and 8 contained a single major compound. The three remaining fractions (2, 3 and 7 ) were mixtures (see supplementary figure 1) and were further fractionated using one or two additional semi-preparative NP-HPLC steps as described in Table 1. NP-HPLC was also used to improve the purity of fractions 5 and 6 and remove minor contaminants. Finally, 14 pure compounds were isolated as amorphous powders and identified by HRESIMS and NMR.

Seven of the 14 have already been described in the Ecdybase (Lafont et al., 2002) i.e., turkesterone (compound 1), atrotosterone C (compound 2.3.1), abutasterone (compound 2.3.2), 20-hydroxyecdysone (compounds 3.2 and 4), 25-hydroxydacryhainansterone (compound 3.3), cyasterone (compound 6) and ajugasterone $\mathrm{C}$ (compound 7.1). The corresponding data are provided as supplementary material. Seven other ecdysteroids were isolated for the first time, and their identification is described below.

Identification of the newly isolated ecdysteroids

The structures of the new ecdysteroids are given in figure 3 . Their ${ }^{1} \mathrm{H}$ and ${ }^{13} \mathrm{C} N M R$ data are given in Tables 2 and 3. Full NMR spectra are provided in the supplementary materials for turkesterone and the 7 new ecdysteroids. All the new compounds isolated in this work present a $5-\mathrm{H} \beta$ steroid nucleus with an $11 \alpha$-hydroxy (equatorial) substituent identical with turkesterone, which result in typical signal characteristics as described for turkesterone (see supplementary 
material and figure s3). Thus the modifications concern only their side-chain with respect to turkesterone.

\section{5-Hydroxyatrotosterone A (Compound 2.1 - $1.6 \mathrm{mg}$ )}

Turbo lon Spray-MS gives positive ions at $\mathrm{m} / \mathrm{z} 511(\mathrm{M}+\mathrm{H})^{+}, 493\left(\mathrm{MH}-\mathrm{H}_{2} \mathrm{O}\right)^{+}, 475\left(\mathrm{MH}-2 \mathrm{H}_{2} \mathrm{O}\right)^{+}$,

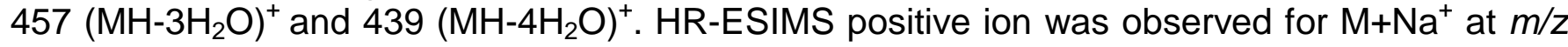
$533.30800\left(\mathrm{~m} / z\right.$ expected for $\left.\mathrm{C}_{28} \mathrm{H}_{46} \mathrm{O}_{8} \mathrm{Na} 533.30849, \Delta=-0.92 \mathrm{ppm}\right)$. The compound formula is $\mathrm{C}_{28} \mathrm{H}_{46} \mathrm{O}_{8}$, which indicates that it bears one additional carbon and two extra hydrogen atoms with respect to turkesterone. Examination of the $1 \mathrm{D}{ }^{1} \mathrm{H}$ NMR spectrum shows a new methyl signal doublet at $0.96 \mathrm{ppm},(\mathrm{d}, 6.8 \mathrm{~Hz})$ bound to $\mathrm{CH}-24$ (figure s4). This $\mathrm{CH}-24$ is assigned from HMBC correlations observed with ${ }^{1} \mathrm{H}$ of $26-\mathrm{Me}$ and $27-\mathrm{Me}$ methyl signals. ${ }^{1} \mathrm{H}$ and ${ }^{13} \mathrm{C}$ NMR signals of methyls 26 and 27 correspond to values in agreement with 25 hydroxylated ecdysteroids. This is confirmed from HMBC correlations observed with ${ }^{1} \mathrm{H}$ of $26,27,28$ methyl signals with the same ${ }^{13} \mathrm{C}$ NMR signal at $76.4 \mathrm{ppm}$ thus assigned unambiguously to C-25. Moreover, ${ }^{1} \mathrm{H}$ and ${ }^{13} \mathrm{C}$ NMR signals of the side-chain are identical with those of makisterone $\mathrm{A}$, both recorded in $\mathrm{D}_{2} \mathrm{O}$ (Bakrim et al., 2014), suggesting that the configuration of the asymmetric center at C-24 is equivalent for these two compounds. Thus, the structure was assigned as 25hydroxyatrotosterone $A$.

\section{1-Hydroxycyasterone (Compound 2.2 - $0.9 \mathrm{mg}$ )}

Turbo lon Spray-MS gives positive ions at $\mathrm{m} / \mathrm{z} 537(\mathrm{M}+\mathrm{H})^{+}, 519\left(\mathrm{MH}-\mathrm{H}_{2} \mathrm{O}\right)^{+}, 501\left(\mathrm{MH}-2 \mathrm{H}_{2} \mathrm{O}\right)^{+}$, $483\left(\mathrm{MH}-3 \mathrm{H}_{2} \mathrm{O}\right)^{+}$and $465\left(\mathrm{MH}-4 \mathrm{H}_{2} \mathrm{O}\right)^{+}$. An HR-ESIMS positive ion was observed for $\mathrm{M}_{+} \mathrm{Na}^{+}$at $\mathrm{m} / \mathrm{z} 559.28768$ ( $\mathrm{m} / \mathrm{z}$ expected for $\left.\mathrm{C}_{29} \mathrm{H}_{44} \mathrm{O}_{9} \mathrm{Na} 559.28775, \Delta=-0.13 \mathrm{ppm}\right)$. The compound formula corresponds therefore to $\mathrm{C}_{29} \mathrm{H}_{44} \mathrm{O}_{9}$, thus it has two additional carbons and one extraoxygen with respect to turkesterone. Examination of $1 \mathrm{D}$ and $2 \mathrm{D}{ }^{1} \mathrm{H}$ NMR spectra (figure s5) shows two methyl signal doublets, one at $1.32 \mathrm{ppm},(\mathrm{d}, 7.2 \mathrm{~Hz}) \mathrm{J}$ coupled to the oxymethine group $\mathrm{CH}-25$, with its ${ }^{1} \mathrm{H}$ signal $25-\mathrm{H}$ at $2.67 \mathrm{ppm},(\mathrm{dq}, 10.8,7.1 \mathrm{~Hz})$ and the other one at 1.45 ppm, $(\mathrm{d}, 6.1 \mathrm{~Hz})$, J-coupled to oxymethine group $\mathrm{CH}-28$, with its ${ }^{1} \mathrm{H}$ signal $\mathrm{H}-28$ at $4.34 \mathrm{ppm}$, (dq, 9.4, 6.1 Hz). HMBC show that these two methyl signals are correlated to the same carbon, assigned unambiguously as $\mathrm{CH}-24$ from $\mathrm{HMBC}$ correlation $22-\mathrm{H}=>\mathrm{C}-24$. Moreover, $24-\mathrm{H}$ presents the reverse HMBC correlation $24-\mathrm{H}=>\mathrm{C}-27$ and $\mathrm{C}-29$ to the ${ }^{13} \mathrm{C}$ signals of these two methyl groups. The ${ }^{1} \mathrm{H}$ methyl signal at $1.32 \mathrm{ppm}$ presents an $\mathrm{HMBC}$ correlation with the ${ }^{13} \mathrm{C}$ signal of an ester carbonyl group at $185.9 \mathrm{ppm}$. All these elements lead us to propose a sidechain with a lactone group as in cyasterone. Moreover, the ${ }^{1} \mathrm{H}$ and ${ }^{13} \mathrm{C} \mathrm{NMR}$ data, when compared with those of cyasterone in $\mathrm{D}_{2} \mathrm{O}$, show that these two compounds have identical sidechains. Side-chain ${ }^{1} \mathrm{H}$ and ${ }^{13} \mathrm{C}$ chemical shifts and both $\mathrm{HMBC}$ and NOESY experiments show identical values and correlations to those observed for cyasterone, suggesting equivalent stereochemistry of the lactone ring. Thus, the structure was assigned as 11-hydroxycyasterone.

\section{1-Hydroxysidisterone (Compound 3.1 - $1.0 \mathrm{mg}$ )}

Turbo lon Spray-MS gives positive ions at $\mathrm{m} / \mathrm{z} 433(\mathrm{M}+\mathrm{H})^{+}, 415\left(\mathrm{MH}-\mathrm{H}_{2} \mathrm{O}\right)^{+}, 397\left(\mathrm{MH}-2 \mathrm{H}_{2} \mathrm{O}\right)^{+}$, $379\left(\mathrm{MH}-3 \mathrm{H}_{2} \mathrm{O}\right)^{+}$and $361\left(\mathrm{MH}-4 \mathrm{H}_{2} \mathrm{O}\right)^{+}$. An HR-ESIMS positive ion is observed for $\mathrm{M}_{+} \mathrm{Na}^{+}$at $\mathrm{m} / \mathrm{z}$ 455.20418 (expected for $\mathrm{C}_{24} \mathrm{H}_{32} \mathrm{O}_{7} \mathrm{Na} 455.20402, \Delta=+0.35 \mathrm{ppm}$ ), thus the compound formula is $\mathrm{C}_{24} \mathrm{H}_{32} \mathrm{O}_{7}$. The compound presents the same steroid nucleus as turkesterone. It is a $\mathrm{C}_{24}$ ecdysteroid lacking 3 carbon atoms, 1 oxygen atom and 12 hydrogen atoms when compared to turkesterone. Again, examination of ${ }^{1} \mathrm{H}$ and ${ }^{13} \mathrm{C}$ NMR data (figure s6) show that side-chain modifications with respect to turkesterone correspond to 3 supplementary unsaturations (or equivalents). Examination of the $1 \mathrm{D}{ }^{1} \mathrm{H}$ NMR spectrum shows two new ethylenic ${ }^{1} \mathrm{H}$ signals at $7.92 \mathrm{ppm},(\mathrm{d}, 5.7 \mathrm{~Hz})$ and $6.15 \mathrm{ppm},(\mathrm{d}, 5.7 \mathrm{~Hz})$ which are J-coupled together. HMBC shows that $17-\mathrm{H}$ at $2.75 \mathrm{ppm}(\mathrm{t}, 9.5)$ is correlated to carbon signals of the side-chain corresponding to C-20 (95.4 ppm), C-21 ( 25.8 ppm) and C-22 (167.2 ppm), this last one corresponding to the chemical shift of an ethylenic carbon bond. From a HSQC, the ${ }^{1} \mathrm{H}$ signal at $7.92 \mathrm{ppm}$ could be assigned as $22-\mathrm{H}$. From $\mathrm{HMBC}, 22-\mathrm{H}$ is correlated to carbon signals of the end of the sidechain corresponding to C-23 (120.9 ppm), an ethylenic carbon, and C-24 (179.0 ppm), a typical 
value for a carbonyl ester or a lactone group. These elements suggest that a cyclic structure is present in the side-chain, corresponding to a five-membered lactone ring with a double bond between C-22 and C-23, similar to that of sidisterone (Girault et al., 1996). Comparison with 1D and $2 \mathrm{D}{ }^{1} \mathrm{H}$ and ${ }^{13} \mathrm{C}$ NMR data for the side-chain of sidisterone in $\mathrm{D}_{2} \mathrm{O}$ (Bakrim et al., 2014) shows perfect agreement indicating that the compound is 11-hydroxysidisterone and suggesting that the configuration of the asymmetric centre at C-20 is equivalent for these two compounds.

\section{Turkesterone 22-acetate (Compound 3.4 - $0.7 \mathrm{mg}$ )}

Turbo lon Spray-MS gives positive ions at $m / z 539(\mathrm{M}+\mathrm{H})^{+}, 503\left(\mathrm{MH}-2 \mathrm{H}_{2} \mathrm{O}\right)^{+}, 485\left(\mathrm{MH}-3 \mathrm{H}_{2} \mathrm{O}\right)^{+}$, $479\left(\mathrm{MH}-\mathrm{CH}_{3} \mathrm{COOH}\right)^{+}, 443\left(\mathrm{MH}-2 \mathrm{H}_{2} \mathrm{O}-\mathrm{CH}_{3} \mathrm{COOH}\right)^{+}, 425\left(\mathrm{MH}-3 \mathrm{H}_{2} \mathrm{O}-\mathrm{CH}_{3} \mathrm{COOH}\right)^{+}$and $407(\mathrm{MH}-$ $\left.4 \mathrm{H}_{2} \mathrm{O}-\mathrm{CH}_{3} \mathrm{COOH}\right)^{+}$. An HR-ESIMS positive ion is observed for $\mathrm{M}_{+} \mathrm{Na}^{+}$at $\mathrm{m} / z 561.30318(\mathrm{~m} / \mathrm{z}$ expected for $\left.\mathrm{C}_{29} \mathrm{H}_{46} \mathrm{O}_{9} \mathrm{Na} 561.30340, \Delta=-0.39 \mathrm{ppm}\right)$. The compound formula is therefore $\mathrm{C}_{29} \mathrm{H}_{46} \mathrm{O}_{9}$. It is $\mathrm{a} \mathrm{C}_{29}$ ecdysteroid with two carbons, one oxygen atom and two hydrogen atoms more than turkesterone. Again, ${ }^{1} \mathrm{H}$ and ${ }^{13} \mathrm{C}$ NMR data (figure s7) show only side-chain modifications with respect to turkesterone. Examination of the $1 \mathrm{D}{ }^{1} \mathrm{H}$ NMR spectrum shows a new methyl signal singlet at $2.17 \mathrm{ppm}$ (s), typical of an acetate group. This is confirmed by HMBC, which shows that this methyl is correlated to a quaternary ester carbonyl at $177.2 \mathrm{ppm}$. The presence of this acetate group at C-22 is confirmed by the large high frequency (downfield) shift of the $22-\mathrm{H}$ signal $(4.85 \mathrm{ppm}$, dd, 10.2, $1.5 \mathrm{~Hz}$ ) with respect to turkesterone or 20 hydroxyecdysone. This leads to the conclusion that the compound is turkesterone 22-acetate.

\section{2-Oxo-turkesterone (Compound 5 - $1.4 \mathrm{mg}$ )}

Turbo lon Spray-MS gives positive ions at $\mathrm{m} / \mathrm{z} 495(\mathrm{M}+\mathrm{H})^{+}, 477\left(\mathrm{MH}-\mathrm{H}_{2} \mathrm{O}\right)^{+}, 459\left(\mathrm{MH}-2 \mathrm{H}_{2} \mathrm{O}\right)^{+}$, $441\left(\mathrm{MH}-3 \mathrm{H}_{2} \mathrm{O}\right)^{+}$and $423\left(\mathrm{MH}-4 \mathrm{H}_{2} \mathrm{O}\right)^{+}$. An HR-ESIMS positive ion is observed for $\mathrm{M}+\mathrm{Na}^{+}$at $\mathrm{m} / \mathrm{z}$ 517.27681 ( $\mathrm{m} / \mathrm{z}$ expected for $\left.\mathrm{C}_{27} \mathrm{H}_{42} \mathrm{O}_{8} \mathrm{Na} 517.27719, \Delta=-0.73 \mathrm{ppm}\right)$. The compound formula is $\mathrm{C}_{27} \mathrm{H}_{42} \mathrm{O}_{8}$, with two missing hydrogen atoms with respect to turkesterone. The side-chain modification with respect to turkesterone corresponds to one supplementary unsaturation. Examination of the 1D ${ }^{1} \mathrm{H}$ NMR spectrum (figure s8) shows disappearance of the ${ }^{1} \mathrm{H}$ signal for $22-\mathrm{H}$ and large high frequencies (downfield) shifts of both $23-\mathrm{Ha}, \mathrm{b}$ of the side-chain (2.79 ppm) with respect to turkesterone. Moreover, HMBC shows that the 21-methyl is correlated to a quaternary carbonyl at 220.4 ppm, a typical value for a ketonic carbonyl, which leads us to conclude that it is a 22-oxo derivative. So, the structure corresponds to 22-oxo-turkesterone.

\section{1-Hydroxy- $\Delta^{24}$-capitasterone (Compound 7.2 - $1.9 \mathrm{mg}$ )}

Turbo Ion Spray-MS gives positive ions at $\mathrm{m} / \mathrm{z} 519(\mathrm{M}+\mathrm{H})^{+}, 501\left(\mathrm{MH}-\mathrm{H}_{2} \mathrm{O}\right)^{+}, 483\left(\mathrm{MH}-2 \mathrm{H}_{2} \mathrm{O}\right)^{+}$, $465\left(\mathrm{MH}-3 \mathrm{H}_{2} \mathrm{O}\right)^{+}, 447\left(\mathrm{MH}-4 \mathrm{H}_{2} \mathrm{O}\right)^{+}$and $429\left(\mathrm{MH}-5 \mathrm{H}_{2} \mathrm{O}\right)^{+}$. An HR-ESIMS positive ion was observed for $\mathrm{M}_{+} \mathrm{Na}^{+}$at $\mathrm{m} / \mathrm{z} 541.27651\left(\mathrm{~m} / \mathrm{z}\right.$ expected for $\mathrm{C}_{27} \mathrm{H}_{42} \mathrm{O}_{8} \mathrm{Na} 541.27719, \Delta=-$ $1.27 \mathrm{ppm})$. The compound formula is therefore $\mathrm{C}_{29} \mathrm{H}_{42} \mathrm{O}_{8}$. The modifications with respect to turkesterone correspond to 3 supplementary unsaturations or equivalents. Examination of 1D and 2D ${ }^{1} \mathrm{H}$ NMR spectra (figure s9) shows 2 new ${ }^{1} \mathrm{H}$ methyl signals. One is a triplet (overlapping the 19-Me singlet) at $1.10 \mathrm{ppm}$, (t, 7.2) J-coupled to a $\mathrm{CH}_{2}$ group at $2.38 \mathrm{ppm}(\mathrm{q}, 7.2)$. This chemical shift corresponds to a $\mathrm{CH}_{2}$ group linked to an ethylenic double bond in agreement with a $\mathrm{CH}_{3}-\mathrm{CH}_{2}-\mathrm{C}=\mathrm{C}<$ motif. The other methyl signal is a singlet at $1.87 \mathrm{ppm}(\mathrm{sb})$, and such a chemical shift corresponds to a methyl linked to an ethylenic double bond. Moreover, HMBC shows that this methyl signal $(1.87 \mathrm{ppm})$ is correlated to two ethylenic carbon signals at 122.2 and $161.7 \mathrm{ppm}$ and with the ${ }^{13} \mathrm{C}$ signal of an ester carbonyl group at $173.5 \mathrm{ppm}$. The $\mathrm{CH}_{2}$ group at $2.38 \mathrm{ppm}$ is also correlated to the same two ethylenic carbon signals. All this leads us to propose a structure for the side-chain of an $\alpha, \beta$-unsaturated lactone. The $22-\mathrm{H}$ signal shows a large high frequency (downfield) shift at $4.38 \mathrm{ppm}(\mathrm{dd}, 13.4,3.5)$ with its corresponding $\mathrm{CH}-22$ signal at $84.4 \mathrm{ppm}$, and these values are in agreement with a lactonization involving the 22hydroxyl group to obtain a six-membered $\alpha, \beta$-ethylenic lactone. This lactone structure is confirmed by all the data obtained from HMBC, HSQC and NOESY and TOCSY experiments. So, the structure of this compound is related to that of capitasterone, a $\mathrm{C}_{29}$ ecdysteroid bearing 
a six-membered lactone ring (Takemoto et al., 1968). Thus, its structure corresponds to 11hydroxy- $\Delta^{24}$-capitasterone.

Turkesterone 20,22-acetonide (Compound 8 - $1.0 \mathrm{mg}$ )

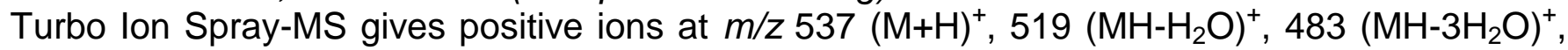
$479\left(\mathrm{MH}-\left(\mathrm{CH}_{3}\right)_{2} \mathrm{CO}\right)^{+}, 461\left(\mathrm{MH}-\mathrm{H}_{2} \mathrm{O}-\left(\mathrm{CH}_{3}\right)_{2} \mathrm{CO}\right)^{+}, 443\left(\mathrm{MH}-2 \mathrm{H}_{2} \mathrm{O}-\left(\mathrm{CH}_{3}\right)_{2} \mathrm{CO}\right)^{+}, 425\left(\mathrm{MH}^{+} 3 \mathrm{H}_{2} \mathrm{O}-\right.$ $\left.\left(\mathrm{CH}_{3}\right)_{2} \mathrm{CO}\right)^{+}$and $407\left(\mathrm{MH}-4 \mathrm{H}_{2} \mathrm{O}-\left(\mathrm{CH}_{3}\right)_{2} \mathrm{CO}\right)^{+}$. An HR-ESIMS positive ion is observed for $\mathrm{M}_{+} \mathrm{Na}^{+}$ at $m / z 559.32346\left(\mathrm{~m} / z\right.$ expected for $\left.\mathrm{C}_{30} \mathrm{H}_{48} \mathrm{O}_{8} \mathrm{Na} 559.32414, \Delta=-1.22 \mathrm{ppm}\right) .{ }^{1} \mathrm{H}$ and ${ }^{13} \mathrm{C} N M R$ data show a single side-chain modification with respect to turkesterone, corresponding to one supplementary unsaturation or equivalent. Examination of $1 \mathrm{D}{ }^{1}$ and $2 \mathrm{D}{ }^{1} \mathrm{H}$ NMR spectra (figure s10) shows 2 new ${ }^{1} \mathrm{H}$ singlet methyl signals at $1.41 \mathrm{ppm}$ (s) and $1.49 \mathrm{ppm}$ (s). Moreover, HMBC shows that these two ${ }^{1} \mathrm{H}$ methyl signals are correlated to the same quaternary carbon atom at $109.8 \mathrm{ppm}$, a typical value for a quaternary carbon of an acetonide group. This acetal group was easily located as bridging $20-\mathrm{O}$ and $22-\mathrm{O}$, as we observe a shift of both $\mathrm{C}-20$ and $\mathrm{C}-22$ to higher frequencies (downfield) at 87.1 and 84.4 ppm, respectively, and similarly for the ${ }^{1} \mathrm{H}-22$ signal at $3.87 \mathrm{ppm}(\mathrm{dd}, 6.4,4 \mathrm{~Hz})$. These findings lead to the straightforward conclusion that it is a 20-22 acetonide derivative. Therefore, the compound corresponds to turkesterone 20,22acetonide.

Thus $A$. turkestanica contains a complex cocktail of ecdysteroids, and additional studies on less polar fractions will probably allow the isolation of even more compounds.

\section{Acknowledgements}

The work presented here was co-funded by the BPI, FUI (French State Fund), Ile de France Region and Seine-Saint-Denis General Council. Dr Laurence Dinan is deeply acknowledged for critical reading of the manuscript and language improvement.

Thanks are due to the colleagues who provided us reference ecdysteroids - Dr Pinheiro (abutasterone) and Dr Harmatha (ajugasterone C) 


\section{REFERENCES}

Abdukadirov IT, Yakubova MR, Nuriddinov KhR, Mamatkhanov AU, Turakhozhaev MT. 2005. Ecdysterone and turkesterone in Ajuga turkestanica determined by HPLC. Chem Nat Comds 41(4):475-476.

Bakrim A, Ngunjiri J, Crouzet S, Guibout L, Balducci C, Girault J-P, Lafont R. 2014. Ecdysteroid profiles of two Ajuga species, A. iva and A. remota. Nat Prod Commun 9(8):1069-1074.

Báthori M, Girault JP, Kalasz H, Mathé I, Dinan LN, Lafont R. 1999. Complex phytoecdysteroid cocktail of Silene otites (Caryophyllaceae). Arch Insect Biochem Physiol 41:1-8.

Báthori M, Kalász H. 2001. Separation methods for phytoecdysteroids. LC-GC Europe, October 2001:2-7.

Cheng DM, Yousef GG, Grace MH, Rogers RB, Gorelick-Feldman J, Raskin I, Lila MA. 2008. In vitro production of metabolism-enhancing phytoecdysteroids from Ajuga turkestanica. Plant Cell Tiss Organ Cult. 93:73-83.

Dinan L. 2009. The Karlson lecture. Phytoecdysteroids: what use are they? Arch Insect Biochem Physiol 72:126-141.

Ganiev ShG, Khamidkhodjaev SA, Djuharova MX, Saatov Z. 1990. Ajuga turkestanica from Baysuntay (Baysun mountain). Uzbek Biol J:30-32 [in Russian].

Girault J-P. 1998. Determination of ecdysteroid structure by 1D and 2D NMR. Russ J Plant Physiol 45:306-309.

Girault J-P, Báthori M, Kalasz H, Mathé I, Lafont R. 1996. Sidisterone, a C-24 ecdysteroid from Silene dioica and Silene otites. J Nat Prod 59:522-524.

Gorelick-Feldman J. Phytoecdysteroids - Understanding their Anabolic Activity. PhD Thesis. Graduate School-New Brunswick Rutgers, The State University of New Jersey. 2009. 143 pp.

Gorelick-Feldman J, MacLean D, Ilic N, Poulev A, Lila MA, Cheng D, Raskin I. 2008. Phytoecdysteroids increase protein synthesis on skeletal muscle cells. J Agric Food Chem 56:3532-3537.

Grace MH, Cheng DM, Raskin I, Lila MA. 2008. Neo-clerodane diterpenes from Ajuga turkestanica. Phytochem Lett 1:81-84.

Israili ZH, Lyoussi B. 2009. Ethnopharmacology of the plants of genus Ajuga. Pak J Pharm Sci 22(4):425-462.

Khalitova YD, Syrov VN, Akhmedkhodjaeva KhS, Mamatkhanov AU. 1998. Possible use of the extract of Ajuga turkestanica as a remedy contributing to lactation. Dokl Akad Nauk Respubliki Uzbekistan 8:35-38.

Kokoska L, Janovska D. 2009. Chemistry and pharmacology of Rhaponticum carthamoides: a review. Phytochemistry 70:842-855.

Kutepova TA, Syrov VN, Khushbaktova ZA, Saatov Z. 2001. Hypoglycemic activity of the total ecdysteroid extract from Ajuga turkestanica. Pharm Chem J 35(11):608-609.

Lafont R, Harmatha J, Marion-Poll F; Dinan L, Wilson ID. 2002. Ecdybase, a free ecdysteroid database. http://ecdybase.org. 
Lawrence MM. 2012. Ajuga turkestanica as a countermeasure against sarcopenia and dynapenia. MS Thesis, Appalachian State University.

Mamadalieva NZ. 2013. Phytoecdysteroids: chemistry and occurrence. In: Natural compounds: Plant Sources, Structure and Properties, Eds. Azimova, S.S, Vinogradova V.I. (New York: Springer Science+Business Media), Vol. 6, 1-308 pp. ISBN 978-0-387-49140-0.

Mamadalieva NZ, El-Readi MZ, Ovidi E, Ashour ML, Hamoud R, Sagdullaev SS, Azimova SS, Tiezzi A, Wink M. 2013. Antiproliferative, antimicrobial and antioxidant activities of the chemical constituents of Ajuga turkestanica. Phytopharmacol 4(1):1-18.

Mamatkhanov AU, Yakubova MR, Syrov VN. 1998. Isolation of turkesterone from the epigeal part of Ajuga turkestanica and its anabolic activity. Chem Nat Comds 34(2):150-154.

Saatov Z, Agzamkhodzhaeva DA, Syrov VN. 1999. Distribution of phytoecdysteroids in plants of Uzbekistan and the possibility of using drugs based on them in neurological practice. Chem Nat Comds 35(2):186-191.

Saatov Z, Syrov VN, Mamatkhanov AU, Abubakirov NK. 1994. Phytoecdysteroids of plants of the genus Ajuga and their biological activity. I. Distribution and chemical structures of the compounds isolated. Chem Nat Comds 30(2):138-145.

Saatov Z, Usmanov BZ, Abubakirov NK. 1977. Phytoecdysones of Ajuga turkestanica. IV. Chem Nat Comds (3):359.

Shakhmurova GA, Syrov VN, Khushbaktova ZA. 2010. Immunomodulating and antistress activity of ecdysterone and turkesterone under immobilization-induced stress conditions in mice. Pharm Chem J 44(1):7-9.

Syrov VN, Khushbaktova ZA, Tolibaev I, Eletskaya NV, Mamatkhanov AU. 1994. Effect of a lipid concentrate from the aboveground portion of Ajuga turkestanica on the metabolic processes and dynamics of healing skin wounds experimentally. Pharm Chem J 28(11):837840.

Syrov VN, Saatov Z, Sagdullaev ShSh, Mamatkhanov AU. 2001. Study of the structure-activityanabolic activity relationship for phytoecdysteroids extracted from some plants of central Asia. Pharm Chem J 35(12):667-671.

Takemoto T, Nomoto K, Hikino Y. 1968. Structure of capitasterone, a novel C29 insect-moulting substance from Cyathula capitata. Tetrahedron Lett (47):4929-4932.

Usmanov BZ, Gorovits MB, Abubakirov NK. 1971. Phytoecdysones of Ajuga turkestanica. Chem Nat Comds (7):520.

Usmanov BZ, Gorovits MB, Abubakirov NK. 1973. Phytoecdysones of Ajuga turkestanica. II. Chem Nat Comds (9):125.

Usmanov BZ, Gorovits MB, Abubakirov NK. 1975. Phytoecdysones of Ajuga turkestanica. III. The structure of turkesterone. Chem Nat Comds (4):484-487.

Usmanov BZ, Rahkes YaV, Abubakirov NK. 1978a. Phytoecdysones of Ajuga turkestanica. VI. 22-Acetylcyasterone. Chem Nat Comds (2):175-178.

Usmanov BZ, Saatov Z., Abubakirov NK. 1978b. Phytoecdysones of Ajuga turkestanica. V. Chem Nat Comds (5):595.

Vvedenskiy, A. 1961. Flora of Uzbekistan. Publ. Akad. Nauk UzSSR, Tashkent. V.5, p. 266-269. 
Zhang XP, Zhang J, Dong M, Zhang ML, Huo CH, Shi QW, Gu YC. 2010. Chemical constituents of plants from the genus Rhaponticum. Chem Biodiv 7:594-609.

Zubeldia JM, Hernández-Santana A, Jiménez-del-Rio M, Pérez-López V, Pérez-Machin R, Garcia-Castellano JM. 2012. In vitro characterization of the efficacy and safety profile of a proprietary Ajuga turkestanica extract. Chin Med 3:215-222. 


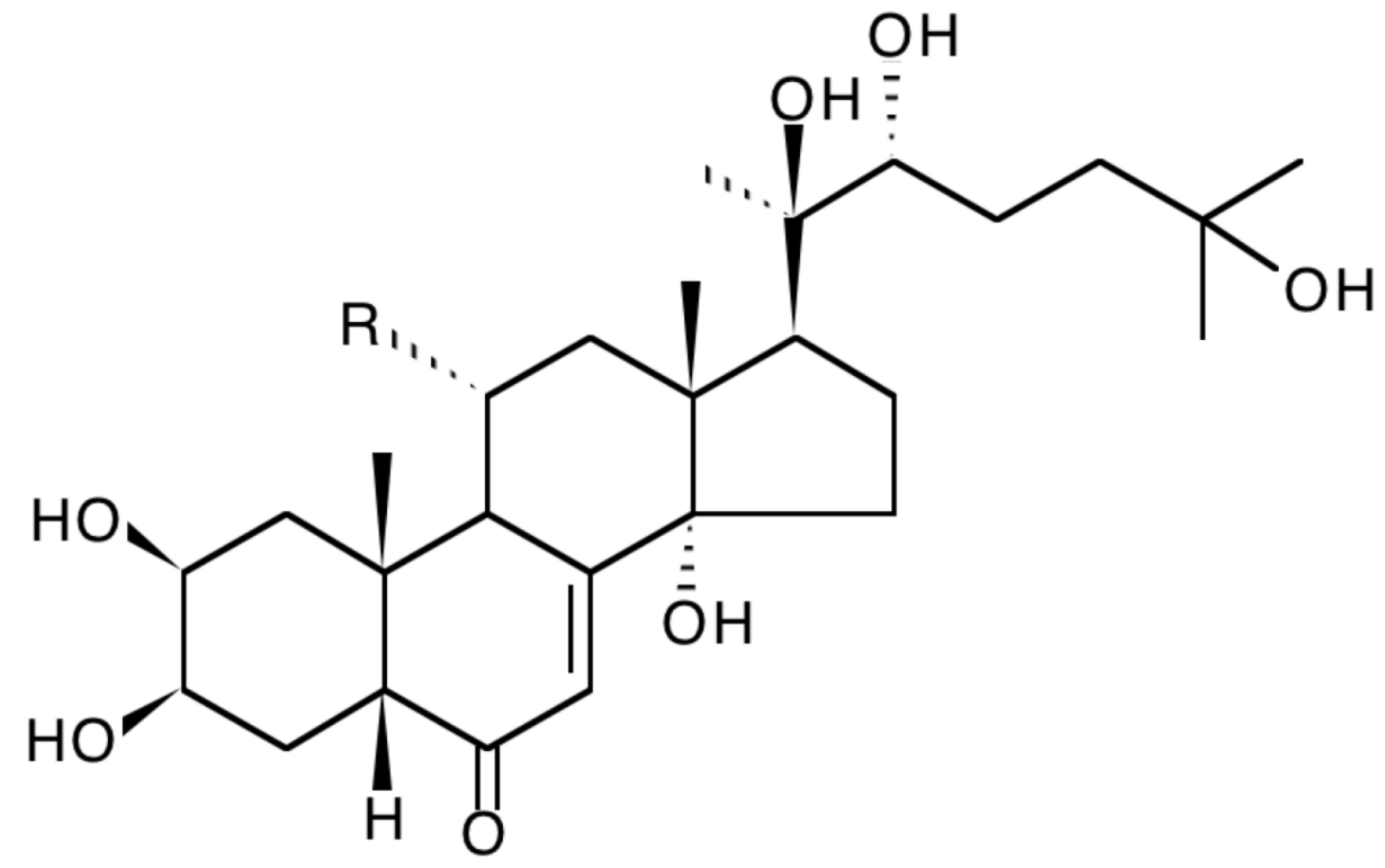

Figure 1. Structure of the two major ecdysteroids from Ajuga turkestanica. $\mathrm{R}=\mathrm{H}: 20$ hydroxyecdysone; $\mathrm{R}=\mathrm{OH}$ : turkesterone. 


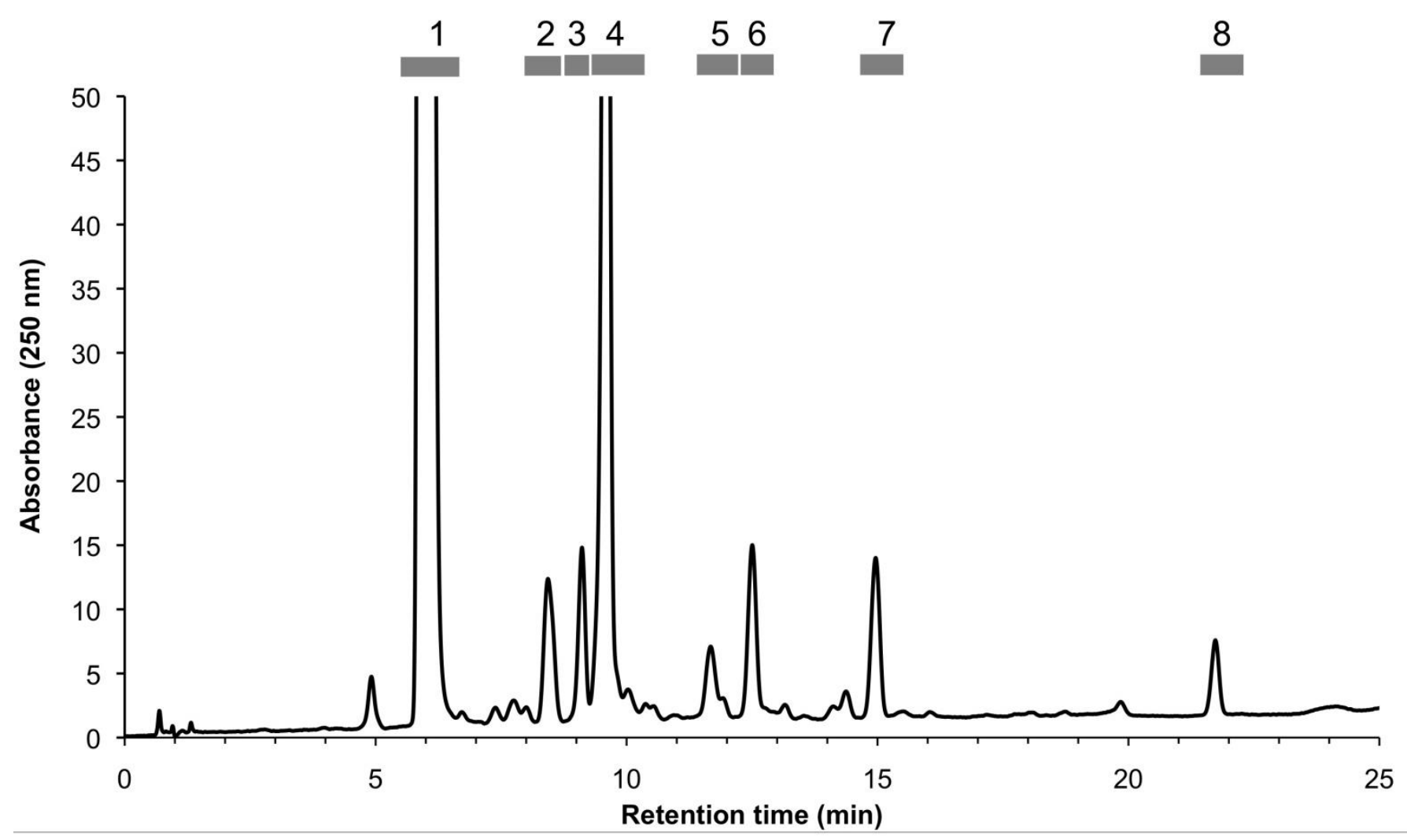

Figure 2. Preparative RP-HPLC chromatogram of the semi-purified A. turkestanica extract. Operating conditions: see text. Eight fractions were collected $(1=$ turkesterone, $4=20$ hydroxyecdysone; for other peaks, see Table 1 and text). 


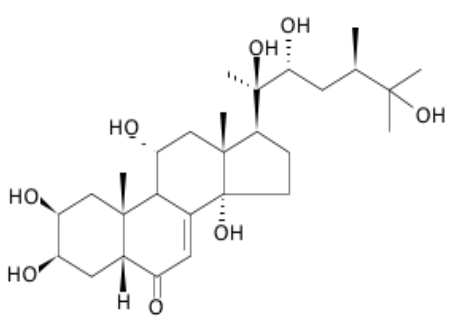

Compound 2.1

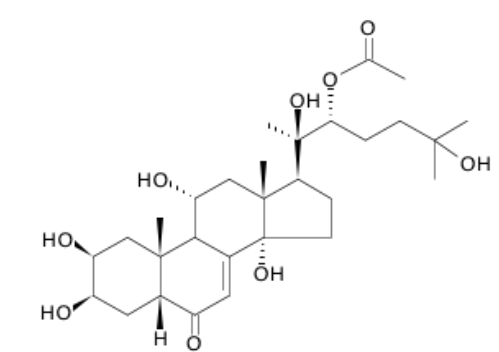

Compound 3.4

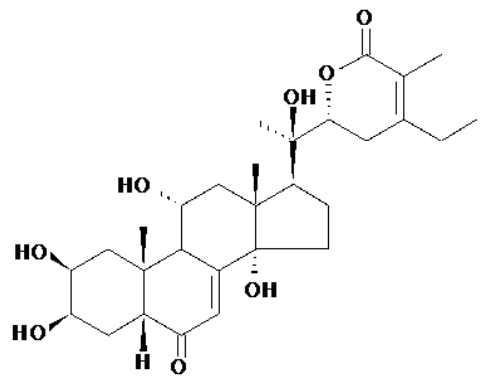

Compound 7.2

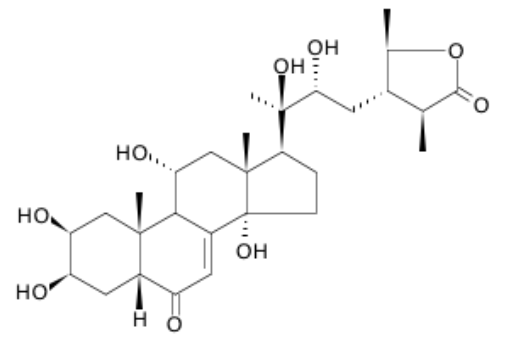

Compound 2.2

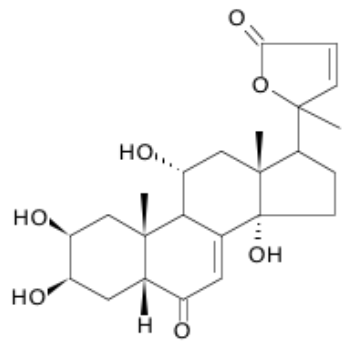

Compound 3.1

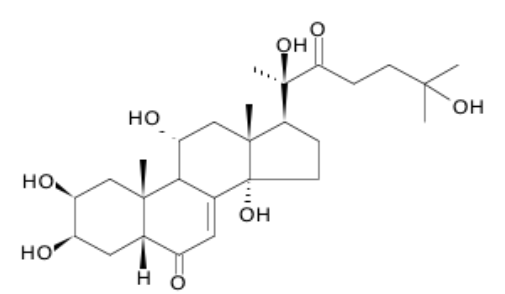

Compound 5

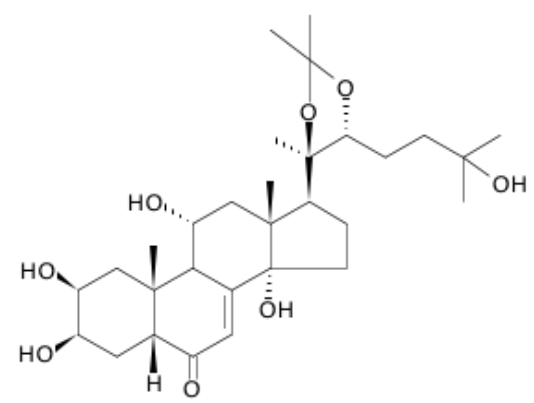

Compound 8

Figure 3. Structural formulae of the 7 new ecdysteroids isolated from Ajuga turkestanica (see names in Table 1). 
Table 1 - HPLC separation of ecdysteroids present in the crude turkesterone extract from $A$. turkestanica.

\begin{tabular}{|c|c|c|c|c|c|c|c|}
\hline \multicolumn{2}{|c|}{ System 1} & \multirow{2}{*}{$\begin{array}{l}\text { System 2a } \\
\text { Ret (min) }\end{array}$} & \multirow{2}{*}{$\begin{array}{l}\text { System 2b } \\
\text { Ret (min) }\end{array}$} & \multirow{2}{*}{$\begin{array}{c}\text { System } \\
3 \\
\text { Ret (min) }\end{array}$} & \multirow{2}{*}{$\begin{array}{c}\text { Compound } \\
\text { number }\end{array}$} & \multirow{2}{*}{ Identification } & \multirow{2}{*}{$\begin{array}{l}\text { Amount isolated } \\
(\mathrm{mg})\end{array}$} \\
\hline Fraction & $\begin{array}{c}\text { Retention } \\
\text { interval (min) }\end{array}$ & & & & & & \\
\hline 1 & $5.10-6.60$ & & & & 1 & Turkesterone & 442.3 \\
\hline 2 & $7.90-8.70$ & $\begin{array}{l}12.83 \\
15.76 \\
25.98\end{array}$ & & $\begin{array}{l}20.00 \\
24.70\end{array}$ & $\begin{array}{l}2.1 \\
2.2 \\
2.3 .1 \\
2.3 .2\end{array}$ & $\begin{array}{c}\text { 25-Hydroxyatrotosterone } A^{*} \\
\text { 11-Hydroxycyasterone } \\
\text { Atrotosterone C } \\
\text { Abutasterone }\end{array}$ & $\begin{array}{l}1.6 \\
0.9 \\
0.1 \\
0.6\end{array}$ \\
\hline 3 & $8.80-9.40$ & & $\begin{array}{l}25.58 \\
35.50 \\
40.65 \\
49.75\end{array}$ & & $\begin{array}{l}3.1 \\
3.2 \\
3.3 \\
3.4\end{array}$ & $\begin{array}{l}\text { 11-Hydroxysidisterone* } \\
\text { 20-Hydroxyecdysone } \\
\text { 25-Hydroxydacryhainansterone } \\
\text { Turkesterone 22-acetate* }\end{array}$ & $\begin{array}{l}1.0 \\
1.1 \\
4.6 \\
0.7\end{array}$ \\
\hline 4 & $9.50-10.50$ & & & & 4 & 20-Hydroxyecdysone & 38.8 \\
\hline 5 & $11.40-12.20$ & 26.80 & & & 5 & 22-Oxo-turkesterone* & 1.4 \\
\hline 6 & $12.30-13.00$ & 6.76 & & & 6 & Cyasterone & 3.4 \\
\hline 7 & $14.60-15.50$ & & & $\begin{array}{l}10.99 \\
19.45\end{array}$ & $\begin{array}{l}7.1 \\
7.2\end{array}$ & $\begin{array}{c}\text { Ajugasterone C } \\
\text { 11-Hydroxy- } \Delta^{24} \text {-capitasterone* }\end{array}$ & $\begin{array}{l}0.8 \\
1.9\end{array}$ \\
\hline 8 & $21.40-22.20$ & 13.95 & & & 8 & Turkesterone 22 -acetonide* & 1.0 \\
\hline
\end{tabular}

${ }^{*}$ New ecdysteroid 
Table 2. ${ }^{1} \mathrm{H}$ NMR data of the newly isolated ecdysteroids.

\begin{tabular}{|c|c|c|c|c|c|c|c|}
\hline${ }^{1} \mathrm{H}$ & $\begin{array}{c}\text { Compound } \\
2.1\end{array}$ & $\begin{array}{c}\text { Compound } \\
2.2\end{array}$ & $\begin{array}{c}\text { Compound } \\
3.1\end{array}$ & $\begin{array}{c}\text { Compound } \\
3.4\end{array}$ & $\begin{array}{c}\text { Compound } \\
5\end{array}$ & $\begin{array}{c}\text { Compound } \\
7.2\end{array}$ & $\begin{array}{c}\text { Compound } \\
8\end{array}$ \\
\hline $\begin{array}{l}1-\mathrm{H}_{\mathrm{ax}} \\
1-\mathrm{H}_{\mathrm{eq}}\end{array}$ & $\begin{array}{c}1.39(\mathrm{t}, 13) \\
2.48 \\
(\mathrm{dd}, 13,3.7)\end{array}$ & $\begin{array}{c}1.39(\mathrm{t}, 13) \\
2.48 \\
(\mathrm{dd}, 13.2,4)\end{array}$ & $\begin{array}{c}1.41(\mathrm{t}, 13) \\
2.50 \\
(\mathrm{dd}, 13,3.9)\end{array}$ & $\begin{array}{c}1.40(\mathrm{t}, 13) \\
2.48 \\
(\mathrm{dd}, 13.1,4)\end{array}$ & $\begin{array}{c}1.40(\mathrm{t}, 12.8) \\
2.48 \\
(\mathrm{dd}, 13,3.9)\end{array}$ & $\begin{array}{c}1.40(t, 13) \\
2.48 \\
(\mathrm{dd}, 13,3.7)\end{array}$ & $\begin{array}{c}1.40(\mathrm{t}, 13) \\
2.48(\mathrm{dd}, 13.1, \\
4)\end{array}$ \\
\hline $2-\mathrm{H}_{\mathrm{ax}}$ & $\begin{array}{c}4.09 \\
\left(\mathrm{~m}, \mathrm{w}_{1 / 2}=11\right)\end{array}$ & $\begin{array}{c}4.09 \\
\left(\mathrm{~m}, \mathrm{w}_{1 / 2}=11\right)\end{array}$ & $\begin{array}{c}4.10( \\
\left.\mathrm{m}, \mathrm{w}_{1 / 2}=12\right)\end{array}$ & $\begin{array}{c}4.10 \\
\left(\mathrm{~m}, \mathrm{w}_{1 / 2}=11\right)\end{array}$ & $\begin{array}{c}4.10 \\
\left(\mathrm{~m}, \mathrm{w}_{1 / 2}=12\right)\end{array}$ & $\begin{array}{c}4.10 \\
\left(\mathrm{~m}, \mathrm{w}_{1 / 2}=10\right)\end{array}$ & $\begin{array}{c}4.09 \\
\left(m, w_{1 / 2}=10\right)\end{array}$ \\
\hline $3-\mathrm{H}_{\text {eq }}$ & $\begin{array}{c}4.09 \\
\left(m, w_{1 / 2}=11\right)\end{array}$ & $\begin{array}{c}4.09 \\
\left(m, w_{1 / 2}=11\right)\end{array}$ & $\begin{array}{c}4.10 \\
\left(m, w_{1 / 2}=12\right)\end{array}$ & $\begin{array}{c}4.10 \\
\left(m, w_{1 / 2}=11\right)\end{array}$ & $\begin{array}{c}4.10 \\
\left(m, w_{1 / 2}=12\right)\end{array}$ & $\begin{array}{c}4.10 \\
\left(m, w_{1 / 2}=10\right)\end{array}$ & $\begin{array}{c}4.09 \\
\left(m, w_{1 / 2}=10\right)\end{array}$ \\
\hline $\begin{array}{l}4-\mathrm{H}_{\mathrm{ax}} \\
4-\mathrm{H}_{\mathrm{ea}}\end{array}$ & $\begin{array}{l}1.74 \\
1.79\end{array}$ & $\begin{array}{l}1.77 \\
1.77\end{array}$ & $\begin{array}{l}1.74 \\
1.79\end{array}$ & $\begin{array}{l}1.74 \\
1.79\end{array}$ & $\begin{array}{l}1.74 \\
1.79\end{array}$ & $\begin{array}{l}1.75 \\
1.79\end{array}$ & $\begin{array}{l}1.74 \\
1.79\end{array}$ \\
\hline $5-\mathrm{H}$ & $\begin{array}{c}2.31 \\
(\mathrm{dd}, 12.3,5.3)\end{array}$ & 2.31 & $\begin{array}{c}2.33(\mathrm{dd}, 12.1, \\
5.4)\end{array}$ & $\begin{array}{c}2.31 \\
(\mathrm{dd}, 12.3,5.3)\end{array}$ & $\begin{array}{c}2.31 \\
(\mathrm{dd}, 12.3,5.3)\end{array}$ & $\begin{array}{c}2.32 \\
(\mathrm{dd}, 12.3,5)\end{array}$ & 2.31 \\
\hline $7-\mathrm{H}$ & $5.98(\mathrm{~d}, 2.6)$ & $5.99(\mathrm{~d}, 2.6)$ & $5.98(\mathrm{~d}, 2.6)$ & $5.99(\mathrm{~d}, 2.6)$ & $5.97(\mathrm{~d}, 2.6)$ & $6.00(\mathrm{~d}, 2.5)$ & $5.99(\mathrm{~d}, 2.6)$ \\
\hline $9-\mathrm{H}_{\mathrm{ax}}$ & $\begin{array}{c}3.13 \\
(\mathrm{dd}, 8.8,2.6)\end{array}$ & $\begin{array}{c}3.13 \\
(\mathrm{dd}, 8.8,2.6)\end{array}$ & $\begin{array}{c}3.13 \\
(\mathrm{dd}, 8.8,2.6)\end{array}$ & $\begin{array}{c}3.13 \\
(\mathrm{dd}, 8.8,2.6)\end{array}$ & $\begin{array}{c}3.14 \\
(\mathrm{dd}, 8.8,2.6)\end{array}$ & $\begin{array}{c}3.14 \\
(\mathrm{dd}, 8.6,2.5)\end{array}$ & $\begin{array}{c}3.13 \\
(\mathrm{dd}, 8.8,2.6)\end{array}$ \\
\hline $11-\mathrm{H}_{\mathrm{ax}}$ & $\begin{array}{c}4.23 \\
\left(\mathrm{~m}, \mathrm{w}_{1 / 2}=27\right. \\
\mathrm{ddd}, 10.8,9,6.1) \\
-\end{array}$ & $\begin{array}{c}4.23 \\
\left(\mathrm{~m}, \mathrm{w}_{1 / 2}=27\right. \\
\mathrm{ddd}, 10.8,9,6.1) \\
-\end{array}$ & $\begin{array}{c}4.20 \\
\text { (m, 12-H } \\
\text { isochronous) }\end{array}$ & $\begin{array}{c}4.22 \\
\left(\mathrm{~m}, \mathrm{w}_{1 / 2}=27\right. \\
\mathrm{ddd}, 10.8,9,6.1) \\
-\end{array}$ & $\begin{array}{c}4.24 \\
\left(\mathrm{~m}, \mathrm{w}_{1 / 2}=27\right) \\
(\mathrm{ddd}, 11,9,6.1) \\
-\end{array}$ & $\begin{array}{c}4.21 \\
\left(\mathrm{~m}, \mathrm{w}_{1 / 2}=27\right) \\
-\end{array}$ & $\begin{array}{c}4.20 \\
\left(\mathrm{~m}, \mathrm{w}_{1 / 2}=27\right) \\
-\end{array}$ \\
\hline $\begin{array}{l}12-\mathrm{H}_{\mathrm{ax}} \\
12-\mathrm{H}_{\mathrm{eq}}\end{array}$ & $\begin{array}{c}2.05) \\
2.28 \\
(\mathrm{dd}, 12.7,6)\end{array}$ & \begin{tabular}{|c|}
2.07 \\
\\
2.28 \\
$(\mathrm{dd}, 12.7,6.1)$
\end{tabular} & $\begin{array}{l}2.13 \\
2.13\end{array}$ & $\begin{array}{c}2.07 \\
(\mathrm{dd}, 12.3,12) \\
2.27 \\
(\mathrm{dd}, 12.7,6)\end{array}$ & $\begin{array}{c}2.16 \\
(\mathrm{t}, 12.3) \\
2.28 \\
(\mathrm{dd}, 12.5 \\
6.1) \\
\end{array}$ & $\begin{array}{l}2.10(\mathrm{~m}) \\
2.15(\mathrm{~m})\end{array}$ & $\begin{array}{c}2.04 \\
2.23 \\
(\mathrm{dd}, 12.7 \\
6.1) \\
\end{array}$ \\
\hline $\begin{array}{l}15-\mathrm{H}_{\beta} \\
15-\mathrm{H}_{\alpha}\end{array}$ & $\begin{array}{l}2.06 \\
1.65\end{array}$ & $\begin{array}{c}2.06 \\
1.66(\mathrm{~m})\end{array}$ & $\begin{array}{l}2.05 \\
1.68 \\
\end{array}$ & $\begin{array}{l}2.06 \\
1.69\end{array}$ & $\begin{array}{c}2.05\left(\mathrm{~m}_{,} \mathrm{w}_{1 / 2}=26\right) \\
1.65\end{array}$ & $\begin{array}{l}2.10 \\
1.70\end{array}$ & $\begin{array}{l}2.05 \\
1.67 \\
\end{array}$ \\
\hline $\begin{array}{l}16-\mathrm{H}_{\alpha}{ }^{*} \\
16-\mathrm{H}_{\beta}{ }^{*}\end{array}$ & $\begin{array}{l}1.90 \\
1.84\end{array}$ & $\begin{array}{l}1.93 \\
1.83\end{array}$ & $\begin{array}{l}1.87 \\
1.51\end{array}$ & $\begin{array}{l}1.89 \\
1.95\end{array}$ & $\begin{array}{l}1.68 \\
1.60\end{array}$ & $\begin{array}{l}1.94 \\
1.88\end{array}$ & $\begin{array}{l}1.96 \\
2.03 \\
\end{array}$ \\
\hline $17-\mathrm{H}$ & $2.32(\mathrm{~m})$ & $2.32(\mathrm{~m})$ & $2.75(\mathrm{t}, 9.5)$ & $2.35(\mathrm{t}, 9.7)$ & $2.62(t, 9.4)$ & $2.53(t, 9.5)$ & $2.32(\mathrm{~m})$ \\
\hline 18-Me & $0.87(\mathrm{~s})$ & $0.87(\mathrm{~s})$ & $0.76(\mathrm{~s})$ & $0.85(\mathrm{~s})$ & $0.84(\mathrm{~s})$ & $0.84(\mathrm{~s})$ & $0.82(\mathrm{~s})$ \\
\hline 19-Me & $1.09(\mathrm{~s})$ & $1.10(\mathrm{~s})$ & $1.10(\mathrm{~s})$ & $1.09(\mathrm{~s})$ & $1.10(\mathrm{~s})$ & $1.10(\mathrm{~s})$ & $1.09(\mathrm{~s})$ \\
\hline $21-\mathrm{Me}$ & $1.26(\mathrm{~s})$ & $1.26(\mathrm{~s})$ & $1.61(\mathrm{~s})$ & $1.36(\mathrm{~s})$ & $1.51(\mathrm{~s})$ & $1.36(\mathrm{~s})$ & $1.27(\mathrm{~s})$ \\
\hline $22-\mathrm{H}$ & $\begin{array}{c}3.55 \\
(\mathrm{~d}, 11)\end{array}$ & $\begin{array}{c}3.63 \\
(d, 10.8) \\
\end{array}$ & $\begin{array}{c}7.92 \\
(\mathrm{~d}, 5.7) \\
\end{array}$ & $\begin{array}{c}4.85 \\
(\mathrm{dd}, 10.2,1.5) \\
\end{array}$ & - & $\begin{array}{c}4.38 \\
\text { (dd } 13.4,3.5) \\
\end{array}$ & $\begin{array}{c}3.87 \\
(\mathrm{dd}, 6.4,4) \\
\end{array}$ \\
\hline $\begin{array}{l}23-\mathrm{Ha} \\
23-\mathrm{Hb}\end{array}$ & $\begin{array}{l}1.25 \\
1.52\end{array}$ & $\begin{array}{c}1.59(\mathrm{~m}) \\
1.76\end{array}$ & $\begin{array}{c}6.15(\mathrm{~d}, 5.7) \\
-\end{array}$ & $\begin{array}{l}1.54(\mathrm{~m}) \\
1.77(\mathrm{~m})\end{array}$ & $\begin{array}{c}2.79(\mathrm{~m}, \\
\left.\mathrm{w}_{1 / 2}=12\right) \\
2.79 \\
\left(\mathrm{~m}, \mathrm{w}_{1 / 2}=12\right) \\
\end{array}$ & $\begin{array}{l}2.62(\mathrm{tb},) \\
2.46\end{array}$ & $\begin{array}{l}1.58 \\
1.58\end{array}$ \\
\hline $\begin{array}{l}24-\mathrm{Ha} \\
24-\mathrm{Hb}\end{array}$ & $\begin{array}{c}1.73 \\
-\end{array}$ & $\begin{array}{c}2.08 \\
-\end{array}$ & - & $\begin{array}{l}1.46(\mathrm{~m}) \\
1.52(\mathrm{~m})\end{array}$ & $\begin{array}{l}1.76 \\
1.76\end{array}$ & - & $\begin{array}{l}1.58 \\
1.71\end{array}$ \\
\hline $25-\mathrm{H}$ & - & $\begin{array}{c}2.67 \\
\text { (dq, } 10.8,7.1) \\
\end{array}$ & - & - & - & - & - \\
\hline $26-\mathrm{Me}$ & $1.18(\mathrm{~s})$ & - & - & $1.22(\mathrm{~s})$ & $1.24(\mathrm{~s})$ & - & $1.247(\mathrm{~s})$ \\
\hline $27-\mathrm{Me}$ & $1.20(\mathrm{~s})$ & $1.32(\mathrm{~d}, 7.2)$ & - & $1.22(\mathrm{~s})$ & $1.24(\mathrm{~s})$ & $1.87(\mathrm{~s})$ & $1.251(\mathrm{~s})$ \\
\hline $28-\mathrm{H}$ & $\begin{array}{c}\text { 28-Me } 0.96 \\
(\mathrm{~d}, 6.8)\end{array}$ & $\begin{array}{l}28-\mathrm{CH} 4.34 \\
\text { (dq, 9.4, 6.1) }\end{array}$ & - & $\begin{array}{c}22-\mathrm{CH}_{3} \mathrm{CO}_{2} \\
2.174(\mathrm{~s})\end{array}$ & - & $\begin{array}{c}28-\mathrm{CH}_{2} 2.38 \\
(\mathrm{q}, 7.2)\end{array}$ & $\begin{array}{c}\mathrm{CH}_{3}(\mathrm{a}) \\
1.41 \text { (s) } \\
\mathrm{CH}_{3}(\mathrm{~b}) 1.49 \\
\text { (s) }\end{array}$ \\
\hline 29-Me & - & $1.45(\mathrm{~d}, 6.1)$ & - & - & - & $1.10(\mathrm{t}, 7.2)$ & \\
\hline
\end{tabular}

Solutions in $\mathrm{D}_{2} \mathrm{O}, \mathrm{T}=300 \mathrm{~K}$; referenced to TSP-d4. Chemical shifts $\delta$ in ppm, $\left.\delta \square \square \mathrm{HDO}\right)=4.758 \mathrm{ppm}, \square \delta \square 19-\mathrm{Me}$ $(20 \mathrm{E})=1.00 \mathrm{ppm}$; Multiplicity of signals $: s$ - singlet; $d$-doublet; $t$ - triplet; $m$ - multiplet; $b r$ - broad signal ; $\mathrm{w}_{1 / 2}$ : width at half-height in Hertz.

*assignments could be reversed. $\mathrm{t}^{*}$ deceptively simple triplet $\left(4-\mathrm{H}_{a x}\right.$ and $4-\mathrm{H}_{e q}$ isochronous) 
Table $3 .{ }^{13} \mathrm{C}$ NMR data of the newly isolated ecdysteroids.

\begin{tabular}{|c|c|c|c|c|c|c|c|c|}
\hline${ }^{13} \mathrm{C}$ & Multiplicity & $\begin{array}{c}\text { Compound } \\
2.1\end{array}$ & $\begin{array}{c}\text { Compound } \\
2.2\end{array}$ & $\begin{array}{c}\text { Compound } \\
3.1\end{array}$ & $\begin{array}{c}\text { Compound } \\
3.4\end{array}$ & $\begin{array}{c}\text { Compound } \\
5\end{array}$ & $\begin{array}{c}\text { Compound } \\
7.2\end{array}$ & $\begin{array}{c}\text { Compound } \\
8\end{array}$ \\
\hline C-1 & $\mathrm{CH}_{2}$ & 39.1 & 39.2 & 39.2 & 39.4 & 39.2 & 39.3 & 39.3 \\
\hline $\mathrm{C}-2$ & $\mathrm{CH}$ & 69.3 & 69.3 & 69.4 & 69.6 & 69.3 & 69.6 & 69.4 \\
\hline C-3 & $\overline{\mathrm{CH}}$ & 69.3 & 69.3 & 69.4 & 69.6 & 69.3 & 69.6 & 69.4 \\
\hline C-4 & $\mathrm{CH}_{2}$ & 33.7 & 33.6 & 33.7 & 33.9 & 33.6 & 33.8 & 33.7 \\
\hline $\mathrm{C}-5$ & $\mathrm{CH}$ & 53.4 & 53.4 & 53.5 & 53.6 & 53.4 & 53.5 & 53.6 \\
\hline C-6 & C & 210.4 & 210.6 & 210.5 & 211.0 & 210.4 & * & * \\
\hline C-7 & $\mathrm{CH}$ & 123.9 & 123.9 & 124.2 & 124.2 & 123.9 & 124.4 & 124.0 \\
\hline C-8 & $\mathrm{C}$ & 167.6 & 167.9 & 166.7 & 167.9 & 166.8 & * & 167.3 \\
\hline C-9 & $\mathrm{CH}$ & 43.4 & 43.4 & 43.4 & 43.7 & 43.4 & 43.7 & 43.4 \\
\hline $\mathrm{C}-10$ & $\mathrm{C}$ & 40.7 & 40.3 & 40.8 & 41.3 & 40.8 & 40.7 & 40.3 \\
\hline C-11 & $\mathrm{CH}_{2}$ & 70.3 & 70.3 & 70.1 & 70.5 & 70.2 & 70.4 & 70.3 \\
\hline C-12 & $\mathrm{CH}_{2}$ & 43.9 & 43.8 & 43.2 & 43.9 & 43.7 & 43.8 & 43.6 \\
\hline C-13 & $\mathrm{C}$ & 49.4 & 49.3 & 48.9 & 49.6 & 49.5 & 49.1 & 49.4 \\
\hline $\mathrm{C}-14$ & $\mathrm{C}$ & 86.6 & 86.6 & 86.7 & 87.2 & 86.8 & 87.1 & 86.3 \\
\hline C-15 & $\mathrm{CH}_{2}$ & 32.4 & 32.5 & 32.3 & 32.7 & 32.4 & 32.6 & 32.3 \\
\hline C-16 & $\mathrm{CH}_{2}$ & 22.0 & 22.1 & 23.3 & 22.6 & 22.3 & 22.5 & 22.9 \\
\hline C-17 & $\mathrm{CH}$ & 50.8 & 50.7 & 52.7 & 51.5 & 51.7 & 51.0 & 51.3 \\
\hline C-18 & $\mathrm{CH}_{3}$ & 19.7 & 19.7 & 20.4 & 20.0 & 19.6 & 20.1 & 19.6 \\
\hline C-19 & $\mathrm{CH}_{3}$ & 25.3 & 25.3 & 25.3 & 25.4 & 25.3 & 25.4 & 25.4 \\
\hline C-20 & $\mathrm{C}$ & 80.2 & 79.9 & 95.4 & 79.3 & 84.0 & 78.1 & 87.1 \\
\hline $\mathrm{C}-21$ & $\mathrm{CH}_{3}$ & 21.5 & 21.3 & 25.8 & 22.5 & 25.6 & 22.2 & 23.1 \\
\hline $\mathrm{C}-22$ & $\mathrm{CH}$ & 76.1 & 75.9 & 167.2 & 82.3 & 220.4 & 84.4 & 84.4 \\
\hline C-23 & $\mathrm{CH}_{2}$ & 35.2 & 35.2 & 120.9 & 26.9 & 34.1 & 30.7 & 25.5 \\
\hline $\mathrm{C}-24$ & $\mathrm{CH}_{2}$ & 42.0 & 49.7 & 179.0 & 41.9 & 38.6 & 161.7 & 42.5 \\
\hline C-25 & $\mathrm{C}$ & 76.4 & 44.4 & - & 73.9 & 73.2 & 122.2 & 72.2 \\
\hline C 26 & $\mathrm{CH}_{3}$ & 27.3 & 185.9 & - & 30.0 & 29.6 & 173.5 & 29.7 \\
\hline $\mathrm{C}-27$ & $\mathrm{CH}_{3}$ & 27.7 & 17.0 & - & 30.0 & 29.6 & 13.6 & 30.0 \\
\hline $\mathrm{C}-28$ & & $\mathrm{CH}_{3}-2815.1$ & $\mathrm{CH}-2884.1$ & - & $\begin{array}{c}22-\mathrm{CH}_{3} \mathrm{CO}_{2} \\
23.1 \\
\end{array}$ & - & $28-\mathrm{CH}_{2} 29.4$ & $\mathrm{CH}_{3}-\mathrm{a}, 28.1$ \\
\hline C-29 & & - & $\mathrm{CH}_{3}-2920.4$ & - & $\begin{array}{c}22-\mathrm{CH}_{3} \mathrm{CO}_{2} \\
177.2 \\
\end{array}$ & - & $29-\mathrm{CH}_{3} 13.1$ & $\mathrm{CH}_{3}-\mathrm{b}, 30.2$ \\
\hline
\end{tabular}

Solutions in $\mathrm{D}_{2} \mathrm{O}, \mathrm{T}=300 \mathrm{~K}$ referenced to TSP- $\mathrm{d}_{4}$. Chemical shifts in ppm.

*signal not detected (too low concentration of the sample) 